\title{
DECISION SUPPORT SYSTEM FOR SELECTION OF EXEMPLARY EMPLOYEES AT PT. SINAR ASIA PERKASA
}

\author{
Syahriani, Nurmah, Luthfi Indriyani \\ Informatics Engineering, Information Systems, \\ Sekolah Tinggi Manajemen Informatika dan Komputer Nusa Mandiri \\ www.nusamandiri.ac.id \\ syahriani.yii@nusamandiri.ac.id,nurmahn15@gmail.com \\ Computer Technology \\ Universitas Bina Sarana Informatika \\ www.bsi.ac.id \\ luthfi.lfy@bsi.ac.id
}

\begin{abstract}
Abstrak
PT. Sinar Asia Perkasa merupakan perusahaan manufaktur, dimana perusahaan ini selalu dituntut untuk melakukan inovasi dan meningkatkan mutu serta kualitas produknya. Karena perihal tersebut, maka perusahaan PT. Sinar Asia Perkasa harus berbenah diri agar mendapatkan karyawan yang memiliki kualitas dan produktivitas kerja yang tinggi. Karyawan merupakan salah satu bagian terpenting dalam perusahaan yang harus dikelola secara baik. Untuk mendapatkan karyawan dengan kualitas terbaik, dibutuhkan proses yang dapat secara langsung memberikan rekomendasi dalam memilih karyawan teladan pada PT. Sinar Asia Perkasa yaitu dengan dibuatkannya Sistem Pendukung Keputusan. Sistem Pendukung Keputusan ini, diharapkan dapat membantu dalam pemilihan karyawan teladan dengan penilaian secara objektif. Pembuatan Sistem Pendukung Keputusan ini menggunakan metode Profile Matching dengan beberapa kriteria yaitu aspek disiplin, aspek integritas, aspek kerjasama, dan aspek prestasi kerja. Kemudian untuk tahapan akhir dari metode ini adalah perankingan.
\end{abstract}

Kata kunci: Profile Matching, Karyawan Teladan, Sistem Penunjang Keputusan

\begin{abstract}
PT. Sinar Asia Perkasa is a manufacturing company, where this company is always required to innovate and improve the quality and quality of its products. Because of this, the company PT. Sinar Asia Perkasa must improve itself to get employees who have high quality and work productivity. Employees are one of the most important parts of a company that must be managed properly. To get employees of the highest quality, a process is needed that can automatically provide recommendations in selecting exemplary employees at PT. Sinar Asia Perkasa, namely by establishing a Decision Support System. This Decision Support System is expected to assist in objectively selecting employees. Making this Decision Support System using the Profile Matching method with several criteria, namely aspects of the discipline, aspects of integrity, aspects of cooperation, and aspects of work performance. Then for the final stage of this method is ranking.
\end{abstract}

Keywords: Profile Matching, Exemplary employees, Decision Support System

\section{INTRODUCTION}

Employees have an important role and are the spearhead for the development of a company or institution. A company that is successful in running its business cannot escape the hard work done by its employees. Therefore, for the smooth running and development of a company, the quality and productivity of its employees need to be improved and maintained properly. PT. Sinar
Asia Perkasa has problems in selecting exemplary employees, where the company still uses a subjective one-way assessment(Purwanto, 2017), (Ricki \& Devitra, 2019) because it does not have a systematic method or indicator that is applied.

PT. Sinar Asia Perkasa needs to improve itself in the process of managing its human resources. If human resources can be well organized, it is hoped that the company can carry 
out all its business processes properly(Penta, Siahaan, and Sukmana, 2019).

Therefore the company PT. Sinar Perkasa requires a decision support system for selecting exemplary employees in its company. Decision Support Systems are part of a computer-based information system including knowledge-based or knowledge management systems that are used to support decision making in an organization or company. (Pareda, Mongi, and Montolalu, 2019). The method used in the decision support system process is the profile matching method. (Sudrajat, 2018), (Mashyur \& Frieyadie, 2019). The concept of the profile matching method is to compare individual competencies into job competencies so that differences incompetence can be found (called GAP). (Triandi, 2011), the smaller the resulting GAP, the greater the weighted value, which means that there is a greater chance for someone to occupy that position (Susilo, 2018). Also, according to Atmanagara et al, this method is very suitable for use in human resource management efforts, because in the process of the profile matching method in outline is a process of comparing individual abilities to competencies that must be achieved in a position (Atmanagara, Putri, and Sutrisno, 2017).

Research on decision support systems for selecting exemplary employees at PT. Sinar Asia Perkasa is made based on data and special criteria used to support employee quality and productivity. The GAP calculation process is carried out to determine the points of each criterion and match the weighting of each criterion. Then the results of the calculation process will produce employee rankings.

\section{RESEARCH METHODS}

This study uses the Profile Matching Method. According to Merlina and Hidayat, the stages and processes of searching for ranking values using the Profile Matching method are as follows (Merlina and Hidayat, 2012):

1. Weighted Value

The weight value is used to find the gap value or the difference between the value of the employee profile and the value of the best employee profile, which can be written with the formula:

$G A P=$ Nilai Karyawan - Nilai Standar $($ Minimum $)$

2. Calculation and Grouping of Core and Secondary Factors
After determining the weight of the gap value, the next step is to calculate and group the values based on the core factor and secondary factor.

a. Core Factor Value Calculation

The calculation of the core factor value is shown in the formula below:

$N R C=\frac{\Sigma N C}{\Sigma I C}$

Information:

NRC: Average value core factor

NC: The total number of the scores core factor

IC: Amount of core factor items

b. Calculation of Secondary Factor Value

The calculation of the second-factor value is shown by the formula below:

$N R C=\frac{\Sigma N C}{\Sigma I S}$

Information:

NRF: Average value secondary factor

NS: The total number of scores secondary factor

IS: Amount of secondary factor item

3. Total Value Calculation

From the results of the weighted value calculation and the grouping of core factor and secondary factor, then the total value is calculated based on the percentage of cores and secondary factors that are estimated to affect the performance of each profile. The formula is as follows:

$N T=[x] \% N C F+[x] \% X N S F$

Information:

NT: The total value of the variable

(x)\%: The percent value entered

NCF: Average value core factor

NSF: Average value secondary factor

4. Ranking Determination Calculations

The final result of the Profile Matching process is ranking. Ranking refers to the results of certain calculations, which are shown in the formula below:

Rangking $=[x] \% X N 1+[x] \% X N 2+$

$[x] \% X N 3+[x] \% X N 4$

Source: (Adhar, 2014)

Information:

N1, N2, N3, N4: The total calculated aspect value

(x)\% : The percent value entered

\section{Likert scale}

The Likert scale is a scale used to measure the attitudes, opinions, and perceptions of a person 
or group of people regarding a symptom or phenomenon that will be used as a benchmark or to test how strong a statement consisting of 5 points, in Table 1 including (Sugiyono, 2016)

Table 1. Likert scale

\begin{tabular}{clc}
\hline No. & \multicolumn{1}{c}{ Information } & Score \\
\hline 1 & Very agree / always / very positive & 5 \\
2 & Agree / often / positive & 4 \\
3 & Indecisive / occasional / neutral & 3 \\
4 & Disagree / almost never / negatively & 2 \\
5 & Strongly disagree / never & 1 \\
\hline
\end{tabular}

\section{Research procedure}

The procedures or stages of this research are:

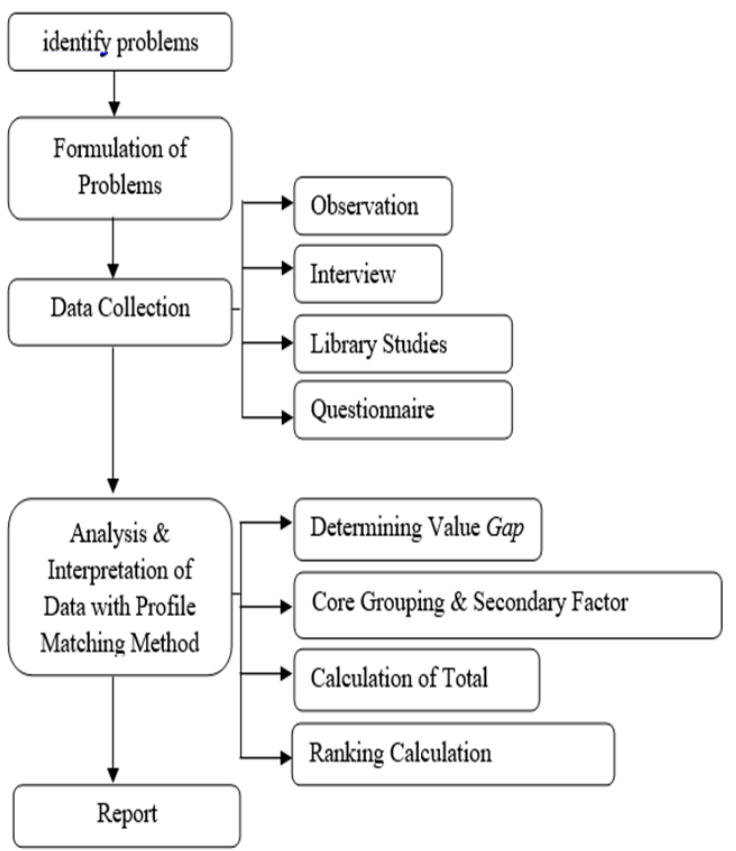

Figure 1. Procedure or Research Stages

\section{Data collection technique}

The research methods used by the authors in conducting this research are:

A. Observation

The data and information obtained related to the selection process for the best employees is direct research at PT. Sinar Asia Perkasa, Penjaringan, North Jakarta.

B. Interview

This study conducted interviews with resource persons, namely Mr. Stevanus Vincent Susanto, SE, as the HRD Manager at the company.

C. Literature review

The author is looking for various references such as books, online journals, previous works, ebooks, literature studies, and others related to the theme the author takes.

D. Questionnaire
The questionnaire is designed in the form of a Likert scale based on the Profile Matching method, namely, there are 5 sub-criteria response values. Value 5 for a very good response, score 4 for a good response, score 3 for an adequate response, score 2 for poor response, and value 1 for very poor response.

\section{Data analysis technique}

\section{Sampling Technique}

The sample was determined by a population at PT. Sinar Asia Perkasa uses the quota sampling technique, which is part of the nonprobability sampling which consists of the Information Technology, Finance \& Accounting, Promotion, Shipping and Security sections, along with the data (taken for example the IT Department) in Table 2.

Table 2. Sample IT Department Employees

\begin{tabular}{lll}
\hline \multicolumn{1}{c}{ No. } & \multicolumn{1}{c}{ Name } & \multicolumn{1}{c}{ Position } \\
\hline 1. & Ahmad Suhelji & IT Hardware \\
2. & Galant Fadhila & IT Design \\
3. & Andi Sulasikin & IT Design \\
4. & Hifsar Septiyawan & Creative Design \\
5. & Muhammad Albanjaari & Digital Account Executive \\
6. & Nadya Alwin & Digital Account Executive \\
\hline
\end{tabular}

\section{Criteria and Sub Criteria}

The criteria and sub-criteria are determined in Table 3 as follows.

Table 3. Criteria and Sub Criteria

\begin{tabular}{|c|c|c|}
\hline No. & Criteria & Sub Criteria \\
\hline \multirow[t]{3}{*}{1.} & Discipline Aspects & Responsible \\
\hline & & Be on Time \\
\hline & & Appearance Polite Manners \\
\hline 2. & Aspects of Integrity & $\begin{array}{l}\text { Professional } \\
\text { Consistent }\end{array}$ \\
\hline 3. & Cooperation Aspects & $\begin{array}{l}\text { Group Work } \\
\text { Participate \& Contribute } \\
\text { Active \& Productive } \\
\text { Helping Colleagues }\end{array}$ \\
\hline \multirow[t]{3}{*}{4.} & $\begin{array}{l}\text { Aspects of Work } \\
\text { Performance }\end{array}$ & $\begin{array}{l}\text { Complete tasks above } \\
\text { standard }\end{array}$ \\
\hline & & $\begin{array}{l}\text { Complete tasks based on } \\
\text { standards }\end{array}$ \\
\hline & & $\begin{array}{ll}\text { Perform } & \text { Performance } \\
\text { Improvements } & \\
\end{array}$ \\
\hline
\end{tabular}

\section{RESEARCH RESULTS AND DISCUSSION}

\section{Classification of Core Factor and Secondary Factor}

After determining the gap from each predetermined aspect, namely the aspect of discipline, aspects of integrity, aspects of cooperation, and aspects of work performance, then next is to determine the core factor and 
secondary factor of each of these sub-criteria can be seen in Table 6 .

A. Core Factor (Main Aspect), is the most favored aspect and has a high value to get the maximum results from this best employee data management.

B. Secondary Factor (Supporting Aspects), is an aspect that supports the main aspects.

Table 4. Core Factor and Secondary Factor

\begin{tabular}{|c|c|c|c|c|}
\hline No. & Aspect & Core & & Secondary \\
\hline 1. & Discipline & $\begin{array}{l}\text { a. Responsible } \\
\text { b. Be on time }\end{array}$ & $\begin{array}{l}\text { c. } \\
\text { d. }\end{array}$ & $\begin{array}{l}\text { Appearance } \\
\text { Politeness }\end{array}$ \\
\hline 2. & Integrity & a. Professional & b. & Consistent \\
\hline 3. & Cooperation & $\begin{array}{ll}\text { a. } & \text { Group Work } \\
\text { b. Participate \& } \\
\text { Contribute } \\
\text { c. Active \& } \\
\text { Productive }\end{array}$ & d. & $\begin{array}{l}\text { Helping } \\
\text { Colleagues }\end{array}$ \\
\hline 4. & $\begin{array}{l}\text { Work } \\
\text { performance }\end{array}$ & $\begin{array}{l}\text { a. Complete tasks } \\
\text { above standard }\end{array}$ & c. & $\begin{array}{l}\text { Complete } \\
\text { tasks based on } \\
\text { standards } \\
\text { Perform } \\
\text { performance } \\
\text { improvements }\end{array}$ \\
\hline
\end{tabular}

\section{Information on the Value of the Aspect Sub Criteria}

Then it can be seen for the sub-criteria aspect values in Table 5 below:

Table 5. Value of Sub Criteria Aspects

\begin{tabular}{ll}
1 & $=$ Less \\
& $2=$ Enough \\
Sub Criteria Value & $3=$ Good \\
4 & $=$ Satisfactory \\
5 & $=$ Very Satisfying \\
\hline
\end{tabular}

\section{Gap Value Calculation}

Table 6 is the calculation result from the aspect of discipline for the Information Technology section.

Table 6. Discipline Aspects of Gap Value WeightIng Results in Part TI

\begin{tabular}{|c|c|c|c|c|c|c|}
\hline \multirow{2}{*}{ No } & \multirow{2}{*}{ Name } & \multicolumn{4}{|c|}{ Disciplinary Aspects } & \multirow{2}{*}{ Ket } \\
\hline & & D1 & D2 & D3 & D4 & \\
\hline 1 & Ahmad Suhelji & 3 & 1 & 2 & 2 & \\
\hline 2 & Galant Fadhila & 2 & 1 & 2 & 3 & \\
\hline 3 & Andi Sulasikin & 2 & 2 & 3 & 4 & \\
\hline 4 & Hifsar Septiyawan & 3.5 & 3 & 3 & 3 & \\
\hline 5 & Muhammad Albanjaari & 2 & 2 & 3 & 5 & \\
\hline 6 & Nadya Alwin & 3 & 3 & 3 & 4 & \\
\hline & Standard Value & 5 & 5 & 4 & 4 & \\
\hline 1 & Ahmad Suhelji & -2 & -4 & -2 & -2 & \multirow{6}{*}{ GAP } \\
\hline 2 & Galant Fadhila & -3 & -4 & -2 & -1 & \\
\hline 3 & Andi Sulasikin & -3 & -3 & -1 & 0 & \\
\hline 4 & Hifsar Septiyawan & -1.5 & -2 & -1 & -1 & \\
\hline 5 & Muhammad Albanjaari & -3 & -3 & -1 & 1 & \\
\hline 6 & Nadya Alwin & -2 & -2 & -1 & 0 & \\
\hline \multicolumn{7}{|c|}{ Convert Value to Weight } \\
\hline 1 & Ahmad Suhelji & 3 & 1 & 3 & 3 & \multirow{6}{*}{ GAP } \\
\hline 2 & Galant Fadhila & 3.5 & 1 & 3 & 4 & \\
\hline 3 & Andi Sulasikin & 2 & 2 & 4 & 5 & \\
\hline 4 & Hifsar Septiyawan & 4 & 3 & 4 & 4 & \\
\hline 5 & Muhammad Albanjaari & 2 & 2 & 4 & 4.5 & \\
\hline 6 & Nadya Alwin & 3 & 3 & 4 & 5 & \\
\hline
\end{tabular}

\section{Calculation and Grouping NCF and NSF}

Table 7 below is the calculation and grouping of NCF and NSF from disciplinary aspects in the field of TI:

Table 7. Core dan Secondary Factor Of Discipline Aspects In Part TI

\begin{tabular}{lccccccc}
\hline \multirow{2}{*}{ Name } & \multicolumn{3}{c}{ Disciplinary Aspects } & & CF & SF \\
\cline { 2 - 5 } & D1 & D2 & D3 & D4 & & NCF=(D1+D2)/2 & NSF=(D3+D4)/2 \\
\hline Ahmad Suhelji & 3 & 1 & 3 & 3 & 2 & 3 \\
Galant Fadhila & 3.5 & 1 & 3 & 4 & 2.25 & 3.5 \\
Andi Sulasikin & 2 & 2 & 4 & 5 & 2 & 4.5 \\
Hifsar Septiyawan & 4 & 3 & 4 & 4 & 3.5 & 4 \\
Muhammad Albanjaari & 2 & 2 & 4 & 4.5 & 3 & 4.25 \\
Nadya Alwin & 3 & 3 & 4 & 5 & 3.5 \\
\hline
\end{tabular}


Calculation of Total Value

Table 8 is a calculation of the total value of the disciplinary aspects of the TI:

Table 8. Total Value of Disciplinary Aspects Section TI

\begin{tabular}{lccccc}
\hline \multirow{2}{*}{ Name } & \multirow{2}{*}{ CF } & \multirow{2}{*}{ SF } & \multicolumn{2}{c}{ Result \% } & N1 \\
\cline { 4 - 6 } & & & NCF (60\%) & NSF(40\%) & NT = 60\%NCF+ 40\%NSF \\
\hline Ahmad Suhelji & 2 & 3 & 1.2 & 1.2 & $\mathbf{2 . 4}$ \\
Galant Fadhila & 2.25 & 3.5 & 1.5 & 1.4 & $\mathbf{2 . 9}$ \\
Andi Sulasikin & 2 & 4.5 & 1.2 & 1.8 & $\mathbf{3}$ \\
Hifsar Septiyawan & 3.5 & 4 & 2.1 & 1.6 & $\mathbf{3 . 9}$ \\
Muhammad Albanjaari & 2 & 4.25 & 1.2 & 1.7 & $\mathbf{3 . 6}$ \\
Nadya Alwin & 3 & 4.5 & 1.8 & 1.8 & \\
\hline
\end{tabular}

Ranking Calculation

For the determination of ranking results obtained from the formula:
Ranking $=(25 \% \mathrm{x}$ Discipline $)+(20 \% \mathrm{x}$ Integrity $)$ $+(25 \% \times$ Cooperation $)+(30 \% \times$ Job Performance $)$

Table 9. Final Results of Ranking Section TI

\begin{tabular}{|c|c|c|c|c|c|c|c|c|c|}
\hline Name & N1 & N2 & N3 & N4 & $\begin{array}{c}\text { N1 } \\
25 \%\end{array}$ & $\begin{array}{c}\text { N2 } \\
20 \%\end{array}$ & $\begin{array}{c}\text { N3 } \\
25 \%\end{array}$ & $\begin{array}{c}\mathrm{N} 4 \\
30 \% \\
\end{array}$ & Final Result \\
\hline Ahmad Suhelji & 2.4 & 3.8 & 4.22 & 3.4 & 0.6 & 0.76 & 1.055 & 1.02 & 3.47 \\
\hline Galant Fadhila & 2.9 & 4.4 & 4.4 & 4.4 & 0.725 & 0.88 & 1.1 & 1.32 & 3.91 \\
\hline Andi Sulasikin & 3 & 4.4 & 4.4 & 4.4 & 0.75 & 0.88 & 1.1 & 1.32 & 4.05 \\
\hline Hifsar Septiyawan & 3.7 & 5 & 4.58 & 4.4 & 0.925 & 1 & 1.145 & 1.32 & 4.39 \\
\hline Muhammad Albanjaari & 2.9 & 4.4 & 4.4 & 4.4 & 0.725 & 0.88 & 1.1 & 1.32 & 4.03 \\
\hline Nadya Alwin & 3.6 & 4.4 & 4.4 & 4.4 & 0.9 & 0.88 & 1.1 & 1.32 & 4.20 \\
\hline
\end{tabular}

Table 10. Section ranking results in TI

\begin{tabular}{lrc}
\hline \multicolumn{1}{c}{ Name } & The final result & Ranking \\
\hline Hifsar Septiyawan & 4.39 & 1 \\
Nadya Alwin & 4.2 & 2 \\
Andi Sulasikin & 4.05 & 3 \\
Muhammad Albanjaari & 4.03 & 4 \\
Galant Fadhila & 4.03 & 5 \\
Ahmad Suhelji & 3.44 & 6 \\
\hline
\end{tabular}

From table 10 can already be seen the final result to select exemplary employees in the FIELD of IT, where the first rank is occupied by Hifsar Septiyawan, the second level is occupied by Nadya Alwin, the third place occupied by Andi Sulasikin, the fourth-place occupied by Muhammad Albanjaari, the fifth-place occupied by Galant Fadhila and the last rank occupied by Ahmad Suhelji.

\section{CONCLUSIONS AND RECOMMENDATIONS}

\section{Conclusion}

Based on the research that has been carried out, it can be concluded that to determine the capacity of employees using profile matching method can be used the results of individual values converted to weight values i.e. by comparing between individual competencies into the competencies of the best employees so that it can be known the difference in competencies (called gaps) which if the resulting gap is smaller then the opportunity to become the best employee is more wide open. Researchers create a decision support system as a tool in making decisions by collecting data, conducting interviews with the parties concerned, analyzing from the data generated by Profile Matching method, gap calculation, core and secondary factor grouping, calculation of yield value to stamping in the place used as a research site namely PT. Sinar Asia Perkasa. Addressing the assessment conducted subjectively is by determining several criteria for the assessment using the profile matching method by giving questionnaires to the boss of each division and the questionnaire results will be calculated so that the questionnaire results can produce accurate data.

\section{Recommendation}

From the results of research conducted on The Decision Support System (SPK) of The Best Employees in PT. Sinar Asia Perkasa, then researchers proposed several suggestions including developing the system by adding methods such as Simple Additive Weighting, Analytical Hierarchy Process, or others so that results may be more accurate. Implement this method by building a web or desktop-based 
decision support system so that decision-makers find it easier and the system more efficient

\section{REFERENCE}

Adhar, D. (2014). Sistem Pendukung Keputusan Pengangkatan Jabatan Karyawan pada PT . Ayn dengan Metode Profile Matching. Jurnal Teknik Informatika Dan Sistem Informasi, 1(1), 16-29.

Atmanagara, F. D. S., Putri, R. R. M., \& Sutrisno, S. (2017). Implementasi Metode Profile Matching untuk Seleksi Penerimaan Anggota Asisten Praktikum ( Studi Kasus : Laboratorium Pembelajaran Kelompok Praktikum Basis Data FILKOM ). Jurnal Pengembangan Teknologi Informasi Dan Ilmu Komputer (J-PTIIK) Universitas Brawijaya, 1(12), 1804-1812. Retrieved from http://j-ptiik.ub.ac.id/index.php/jptiik/article/view/663

Mashyur, R. S., \& Frieyadie, F. (2019). Penggunaan Metode Profile Matching Untuk Pemilihan EOSH Captain Terbaik Pada PT.Coca-Cola Indonesia. Jurnal Pilar Nusa Mandiri, 15(2), 235-240.

https://doi.org/10.33480/pilar.v15i2.767

Pareda, S., Mongi, C. E., \& Montolalu, C. E. J. C. (2019). Sistem Pendukung Keputusan Pemilihan Karyawan Teladan di PT Aneka Tambang ( ANTAM ) Tbk Unit Bisnis Pertambangan Buli Menggunakan Metode Simple Additive weight ( SAW ). D'Cartesian: Jurnal Matematika Dan Aplikasi, 8(1), 1-10. Retrieved from https://ejournal.unsrat.ac.id/index.php/deca rtesian/article/view/22676

Penta, M. F., Siahaan, F. B., \& Sukamana, S. H. (2019). Sistem Pendukung Keputusan Pemilihan Karyawan Terbaik Menggunakan Metode SAW pada PT. Kujang Sakti Anugrah. JSAI (Journal Scientific and Applied
Informatics), $\quad 2(3), \quad 185-192$. https://doi.org/10.36085/jsai.v2i3.410

Purwanto, H. (2017). Penerapan Metode Profile Matching Dalam Sistem Pendukung Keputusan Penilaian Kinerja Karyawan Pada Pt. Hyundai Mobil Indonesia Cabang Kalimalang. Jurnal Techno Nusa Mandiri, 14(1), 15-20.

Ricki, R., \& Devitra, J. (2019). Analisis Dan Perancangan Sistem Pendukung Keputusan Pemilihan Karyawan Terbaik Pada Pt. Wahyu Perdana Persada Dengan Metode Simple Additive Weighting (SAW). Jurnal Manajemen Sistem Informasi, 4(3), 255-265. https://doi.org/10.33998/JURNALMANAJEM ENSISTEMINFORMASI.2019.4.3.658

Sudrajat, B. (2018). Pemilihan Pegawai Berprestasi Dengan Menggunakan Metode Profile Matching. Journal of Information System, Applied, Management, Accounting and Research, 2(4), 20-28. Retrieved from http://polgan.ac.id/jurnal/index.php/sinkro n/article/177/

Sugiyono. (2016). Metode Penelitian Kuantitatif Kualitataif dan Kombinasi (Mixed Methods). Alfabeta.

Susilo, A. A. T. (2018). Penerapan Metode Profile Matching Pada Sistem Pendukung Keputusan Pemilihan Ketua Program Studi (STUDI Kasus : Program Studi Teknik Informatika STMIK Musi Rawas). JUITA : Jurnal Informatika, 5(2), 87-93.

https://doi.org/10.30595/juita.v5i2.1939

Triandi, B. (2011). SISTEM PENDUKUNG KEPUTUSAN UNTUK KENAIKAN JABATAN MENGGUNAKAN METODE PROFILE MATCHING MODELING. JURNAL DIGIT, 1(2), 143-152. Retrieved from https://jurnaldigit.org/index.php/DIGIT/arti cle/view/6 